\title{
The mission, vision and values in hospital management
}

\author{
Amélia Rego*1, Beatriz Araújo², Daniel Serrão ${ }^{1}$ \\ ${ }^{1}$ Universidade Católica Portuguesa - Gabinete de Investigação de Bioética, Porto, Portugal \\ ${ }^{2}$ Universidade Católica Portuguesa - Centro de Investigação Interdisciplinar de Ciências da Saúde, Porto, Portugal
}

Received: September 25, 2015

DOI: $10.5430 /$ jha.v5n1p62
Accepted: November 19, $2015 \quad$ Online Published: November 24, 2015

URL: http://dx.doi.org/10.5430/jha.v5n1p62

\begin{abstract}
Objective: Management depends on choices, on the hierarchy of actions, goals and values on which these decisions are founded, because values guide our actions. This study aims to identify the contents exposed in the vision, mission and values of the hospitals in the north of Portugal. It also aims to analyze the existence of content differentiation, based on the implemented management model.

Methods: The design of this study is exploratory, descriptive, and explanatory. Thus, the data qualitative analysis was performed on the contents of the mission, values and vision publicized on the web pages available on $12^{\text {th }}$ and $13^{\text {th }}$ April 2014 in 36 Hospitals/Medical Centers of the National Health Service and hospitals linked with the Ministry of Health, for the purpose of the Integrated Management System of Subscribers to Surgery.

Results: According to the definition of their mission, values and vision, the values on which hospitals are anchored focus on assistance, organization and management, quality, ethics and social responsibility. The expression of spirituality is limited to two hospitals. As for the hospital's mission, spirituality is expressly assumed in six of the hospitals. Regarding the implemented management model, hospitals explicitly present their values, mission and vision, whether they are integrated into the National Health Service, irrespective of their legal nature (Public-Private Partnership or Public Enterprise), whether they are from the private or social sector. All of them claim to have ethical values, expressing the need to promote human dignity, the quality in the various areas and the holistic care to be provided. The concern of the private sector to add value for its employees, recipients and shareholders stands out.

Conclusions: Managers recognize that ethics and human values are the foundation for the functioning of hospitals. They are aware that the mission, values and vision constitute accreditation criteria, acknowledging that they have a global reach. In the Social Sector, they are declared in the Quality Policy and in hospitals with a Public Enterprise management model they are framed in the Institutional Ethics Code.
\end{abstract}

Key Words: Hospital, Mission, Vision, Values, Management, Organizational ethics

\section{INTRODUCTION}

Society is founded on the values of respect, tolerance, love, solidarity, justice, truth and responsibility. In general, and particularly in hospitals, the health manager has the added responsibility of providing high standards of ethics in the management practice. If the ethical and anthropological di- mensions must underlie all human activity, in the hospital, considering the vulnerability of the people who serve it, they become even more pressing. According to Massarolo and Fernandes, ${ }^{[1]}$ "ethics should be considered as an essential part of the Organization's policy and essential for its development and growth, since the choice of values that humanize

\footnotetext{
*Correspondence: Amélia Rego; Email: ameliarego52@gmail.com; Address: Praça Dr. Cândido Costa Pires, $n^{\circ} 2$ - $4^{\circ}$ Esquerdo, 4715-402 Braga, Portugal. 
the process of work and the relationships with customers brings benefits for the company and for society" by integrating the informal structure, giving meaning to the work that it develops and showing how policies and proposals govern the organizational dynamics.

The mission of a hospital represents its reason to exist, the definition of its role in the community and the inherent responsibilities, i.e., it establishes the service it provides to society. In this sense, it refers the employees to a common orientation and helps to define the organizational objectives, making them more operative. In addition, hospitals have their own organization and, according to Flores, ${ }^{[2]}$ because they are governed by values that guide their actions, they determine their operation and condition the encounter between the health professional and the patient.

The mission statement should result from joint synergies between people, particularly in the levels of strategic, intermediate and operational management, so that their meaning is consistent and clear to everyone. Thus, as stated by Rodríguez, ${ }^{[3]}$ the Hospital should provide public knowledge of the mission, philosophy, values, principles and rules that constitute the Code of Ethics, considering that it is a moral, legal and social responsibility.

On the whole, the reflections regarding the dilemmas that may be present daily in the health institutions determine the need to express the mission and values by which everyone must guide themselves because "bioethics is reflection but it is also action". ${ }^{[4]}$

The contents within the vision, mission and values expressed in the hospitals' frameworks are addressed to everyone, whether they are collaborators or users, because the ethical intentionality to manage linked to values will have the expression of a holistic care to the person as a visible final result. $^{[5]}$

The vision associated with the mission, principles or values translates the strategy followed by the hospital as an institution. It promotes good practice via an ethical culture of quality of service, humanization and respect for the dignity of each person. The ethical dimension of management makes it likely that all professionals in Health Units management are guided by an ethical behavior, acting in accordance to the mission and values, because "no one can take high levels of engagement and commitment to the organization in which it operates if a clear consistency between declared principles and developed practices is not perceived". ${ }^{[6]}$ We also believe that the existence of coherence between the values expressed in the mission and its translation into the reality of the institutions are factors that should be considered for their success.

Mezomo $^{[7]}$ understands the "mission, vision, values and principles as foundations for the quality of life of the organizations". In order to fulfill its objectives and tasks, each hospital incorporates in its conceptual matrix evidence of the vision, mission, values and principles that identify it as an institution and constitute reference.

Values can also be considered "the basic principles of reference that the organization and its staff intend to respect and the principles that are the fundamental rules, doctrines, regulations and assumptions by which managers and employees are expected to act" ${ }^{[8]}$ Thus, the principles support the values and establish the basic priorities and fundamental expectations.

Values can be linked to the organizational system or to the person. The management success lies in the appropriate switching and integration between the values oriented towards the organization and focused on the person, that is, managing by values favors a changing climate that welcomes people and their values. ${ }^{[9]}$ In this framework, it is intended that the principles, values or beliefs establish themselves as decision-making guides, that they guide behavior, evidencing ethics and motivating action, referenced by the content of the mission in order to also achieve the vision of the future. However, we share the opinion of Zoboli and Fracolli ${ }^{[8]}$ when they state that health care takes place in institutions that use tools and forms of management that should focus on people, managing by values such as those associated with the vision and mission of the institution and the instrumental values (also called operating values) that link to the thinking and acting. They also express that managing by values facilitates the inclusion of principles or ethical references in the culture of organizations.

The organizational leadership that is established in the teams also interferes in the achievement of the goals. "Direction by values is a powerful and valuable tool to achieve what the organization asserts as excellence in organizational ethics, but this excellence should not be sought only in the internal environment, for the respect for human rights and the environment are also obligations of an ethics organization governed by values", ${ }^{[9]}$ taking into consideration the future generations and all of humanity.

The vision of the future of an organization must contain at least the following concerns: (1) the sector in which it operates; (2) in which markets will it compete; (3) which goods and services will it offer; (4) what kind of value will it offer to its customers; (5) which long-term advantages will it have; and (6) what will be its performance and profitability. ${ }^{[10]}$ 
The vision of the future of any company must make a commitment to internal and external customers. Therefore, the vision attends to the effect of the anticipated changes and initiates these organizational change processes. The vision should also be shared and should take into perspective the medium term, being both comprehensive and detailed, challenging and motivating, and predisposed to innovation.

It is impossible for an organization to succeed if it is not administered according to a vision of the future in which employees are motivated, because the vision serves the purpose of gathering everyone under the same common effort of the organization's revitalization and to create a cordial atmosphere of commitment and solidarity. ${ }^{[7]}$

The North Regional Health Authority in Portugal ${ }^{[11]}$ incorporates the stated concepts, expressing them on its website as the reason for the existence of the Organization. It also includes the recipients of its action and the professionals who will perform the activities that the organization wants to develop (mission), as well as principles that guide their daily intervention (values) and looking ahead in the future that it wants to provide (vision). Thus, the mission is to ensure that the population of the northern region have access to quality health care, adapting the available resources to their health needs. The values set by the organization include equity, accessibility, responsibility, transparency, knowledge, quality and innovation. The vision is to be recognized by the public as an organization of excellence, able to optimize the human, material and financial resources, ensuring, across the health region, services with differentiation and with technical and professional quality, providing more and better health, confidence and satisfaction, both from users and professionals.

In summary, hospitals are guided by beliefs and values that express their mission, aiming to achieve their organizational goals. Such beliefs and values, formally expressed, guide the decisions of managers at all levels of the organizational structure, indicating which route should be followed within the several viable alternatives of action.

This research stems from the need to identify and internalize the content of the mission, vision and values by professionals and its incorporation in the management and practice of care, with repercussions in the quality and humanization of health care.

The lack of studies published in this field, both nationally and internationally, and the recognition of its importance, constitute the reason for the development of this article.

The purpose of this study is to identify the contents exposed in the vision, mission and values in hospitals of the northern area of Portugal and analyze the existence of content differ- entiation, based on the implemented management model.

\section{METHODS AND MATERIALS}

This study, under a qualitative paradigm, is an exploratory, descriptive, and explanatory research.

The qualitative data analysis was performed on the mission, values and vision publicized on the web pages of 36 of the 62 hospitals that are part of the Northern Regional Health Authority, Public Institute, which had hospitalization. The pages were accessed online on $12^{\text {th }}$ and $13^{\text {th }}$ April 2014.

The hospitals that make up our sample belong to the Public, Private and Social Sectors. From the hospitals under study, 16 are part of the public sector. Those hospitals have the bigger dimension and differentiation and include university education, in the pre and post-graduate training of doctors, nurses and other health workers. Therefore, it is mostly these hospitals that best encourage research in order to contribute to the development of science and health technology. The number of beds per hospital varies from 705,556 or 151 , depending on whether they are general or specialized hospitals.

According to the Central Administration of the Health System, ${ }^{[12]}$ in July 2015, in the Northern region, the actual capacity was 7,032 beds, with an occupancy rate of $88.6 \%$ and a monthly average of 3.6 outgoing patients per bed.

The content analysis technique was supported by a rationale made explicit on the text, whose features were inventoried, allowing us to draw a few conclusions.

We have followed the methodological steps recommended for the thematic content analysis proposed by Bardin. ${ }^{[13]}$ The categories can be found in Tables 2 to 5 (results that express the mission of hospitals), in Table 6 (results that express the values of hospitals), and in Tables 7 to 9 (results expressing the vision of hospitals), and in the presentation of the research data.

The categorization criteria was semantic, in which we did a thematic analysis that, according to Bardin ${ }^{[13]}$ consists in "discovering the units of meaning that make up the communication", which will have a meaning for the chosen analytical objective. The categorization system was chosen by analogy or "mile", a system to which is assigned a conceptual title in the end of the operation. After categorization, we proceeded with the detection of the presence or absence of these categories in the "corpus" by determining units of analysis. These include registration units, context units and enumeration units: Determination of registration units, i.e., the discovery of content segments that make up the communication and can bring input to an analytical target, the most valued features by managers in their concepts of mission, val- 
ues and vision, according to the information available on the institutional web page and according to the predefined categories and rules of enumeration or quantification, in order to determine the frequency with which the items appear. Thus, the importance of the registration unit is directly proportional to its frequency of appearance.

\section{RESULTS}

Of the 36 hospitals under study, from a qualitative paradigm, $16(44.4 \%)$ belong to the National Health Service, one of which in partnership with the National Health Service and a private group; 20 hospitals $(55.6 \%)$ fall into hospitals from the private and social sectors, called to cooperate as part of the Integrated Management System of Subscribers to Surgery.
Table 1. Distribution of hospitals according to the management model

\begin{tabular}{lll}
\hline Hospital management model & $\mathbf{N}^{\mathbf{0}}$ & $\mathbf{\%}$ \\
\hline Private & 9 & 25.0 \\
Public Enterprise & 15 & 41.7 \\
Public-Private Partnership & 1 & 2.8 \\
Private Institutions of Social Solidarity & 11 & 30.5 \\
Total & 36 & 100 \\
\hline
\end{tabular}

Table 1 presents the distribution of hospitals according to the management model. Regarding the management model, hospitals are distributed by: Public-Private Partnership, 1 (2.8\%); Public Enterprise, 15 (41.7\%); Private, 9 (25\%); and Social, $11(30.5 \%)$. We emphasize the preponderance of hospitals with a Public Enterprise model, followed by the Social Sector (Private Institutions of Social Solidarity).

Table 2. Categories and registration units related to the mission of the hospitals

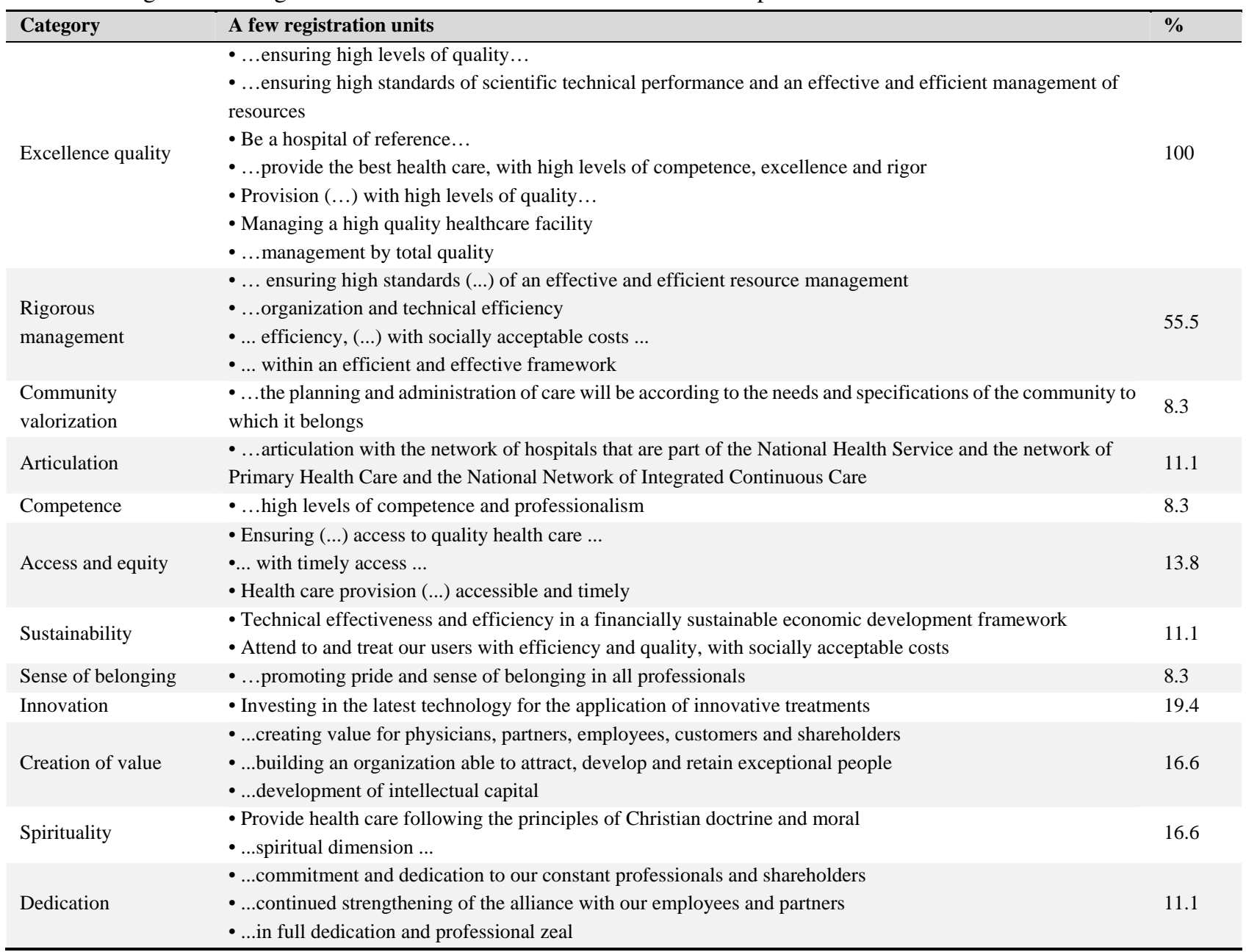

As for the content analysis performed within the mission of the hospitals under study, we present a series of Tables which show results that express the mission of hospitals (see Tables 2 to 5$)$. 
We transformed the qualitative variables into quantitative by the percentages inserted in the Tables, which refer to each category.

In Table 2, we begin the presentation of the categories and some of the registration units related to the mission of the hospitals. Quality and excellence are referred in the mission of all hospitals (100\%). The other categories mentioned in the mission are Rigorous management (58.2\%); Community valorization (8.3\%); Articulation related to the different levels of provision of health care (11.1\%); Competence (8.3\%); Access and equity (13.8\%); Sustainability (11.1\%); Sense of belonging (8.3\%); Innovation (19.4\%); Value creation (16.6\%); Spirituality (16.6\%); and Dedication (11.1\%).

Table 3. Category "Ethics" and Subcategories of signification in the mission of the hospitals

\begin{tabular}{|c|c|c|}
\hline Subcategories & A few units of registrations & $\%$ \\
\hline Values & $\begin{array}{l}\text {-...frame of references and ethical framework } \\
\text { - Managing a healthcare facility (...) strongly committed to the organization, its mission and values } \\
\text {-... privileging those most in need, based on the spirit of solidarity } \\
\text { - Adhere to the highest ethical and professional standards } \\
\text { - Comprehensive care: within physical, social, psychological, cultural, ethical, relational and spiritual dimensions }\end{array}$ & 55.5 \\
\hline Humanization & $\begin{array}{l}\text { - To provide a comprehensive, integrated and personalized service } \\
\text {-... while respecting the principle of humanization, creating a sense of attachment and trust in employees and clients } \\
\text {-... ensure high levels of humanism ... } \\
\text { •... human quality within a healthcare chain } \\
\text { •... provide personalized health care } \\
\text { • Provide humanized health care and social support to the general population } \\
\text {-...proximity and humanization in a biopsychosocial and spiritual perspective of the people who come to us } \\
\text {-...provide its clients with individualized and humanized care } \\
\text { - Promote personalized attention }\end{array}$ & 66.6 \\
\hline Welfare & -... welfare for all employees and/or entities that collaborate with us & 5.5 \\
\hline $\begin{array}{l}\text { Centralization / } \\
\text { dignity of the person }\end{array}$ & $\begin{array}{l}\text {-... obedience to the principle to which it is the center of the system } \\
\text {-... always with the customer participation } \\
\text {-... the planning and administration of care (...) according to individual needs and specifications } \\
\text { •... full respect for the dignity of the person in all their needs, their suffering and their hope } \\
\text {-... respecting the primacy of life }\end{array}$ & 25.0 \\
\hline Respect & $\begin{array}{l}\text {-... respect for the freedom of the person and moral, social and ethical values } \\
\text { - Respect for life } \\
\text {-... absolute respect for the individuality of the patient }\end{array}$ & 14.4 \\
\hline
\end{tabular}

Table 3 presents the category "Ethics" with subcategories of signification in the mission of the hospitals and registration units. In the category "Ethics", we fit the subcategories Values $(55.5 \%)$, Humanization (66.6\%), Welfare $(5.5 \%)$, Centralization/Dignity of the Person (25\%) and Respect (14.4\%).
Table 4 presents the category "Education/training/research" and subcategories of signification in the mission of the hospitals with some registration units. The subcategories are the following: Pre-graduate (36.1\%), Postgraduate (22.2\%), Personal and professional development of employees (44.4\%) and Research (47.2\%).

Table 4. Category "Education/training/research" and Subcategories of signification in the hospital mission

\begin{tabular}{|c|c|c|}
\hline Subcategories & A few registration units & $\%$ \\
\hline Undergraduate & $\begin{array}{l}\text { - Ensure the necessary conditions for (...) pre-graduate medical education ... } \\
\text { •... participation in education and pre-graduate training of health service personnel }\end{array}$ & 36.1 \\
\hline Postgraduate & - Participation in postgraduate education and training of technical health personnel ... & 22.2 \\
\hline $\begin{array}{l}\text { Personal and professional } \\
\text { development of employees }\end{array}$ & $\begin{array}{l}\text { •... stimulating internal qualification and training } \\
\text { •... professional development of (...) employees }\end{array}$ & 44.4 \\
\hline Research & $\begin{array}{l}\text { - Ensure the necessary conditions for (...) scientific research and scientific development in all areas of } \\
\text { health sciences }\end{array}$ & 47.2 \\
\hline
\end{tabular}


Table 5. Category "Providing health care" and Subcategories of signification in the mission of the hospitals

\begin{tabular}{|c|c|c|}
\hline Subcategories & A few registration units & $\%$ \\
\hline Health needs & - Identify the health needs of the population within their area of influence. & 5.5 \\
\hline Treatment & $\begin{array}{l}\text { - To ensure the implementation of health services that make up the production (...) according to the care profile } \\
\text { - To provide a comprehensive, integrated and personalized service } \\
\text {-... the provision of health care in due time, focused on the patient } \\
\text {-... to promote the overall development of customers and meet their basic needs and/or daily life activities } \\
\text { - Promoting comprehensive care in all dimensions } \\
\text { - Diagnose and treat quickly and effectively } \\
\text {-... provide valuable health care }\end{array}$ & 72.2 \\
\hline $\begin{array}{l}\text { Health } \\
\text { promotion }\end{array}$ & $\begin{array}{l}\text { - To promote health in order to contribute to the physical, mental and social well-being of the human person } \\
\text { •... health promotion and protection }\end{array}$ & 19.4 \\
\hline Prevention & •...prevent and fight disease... & 8.3 \\
\hline Rehabilitation & -... rehabilitation and specialized technical assistance & 5.4 \\
\hline Health education & -...education and protection & 2.7 \\
\hline Palliation & $\begin{array}{l}\text { - Carry out palliative actions to hospitalized users and constituting, forming and maintaining an in-hospital support } \\
\text { team in Palliative Care }\end{array}$ & 2.7 \\
\hline
\end{tabular}

In Table 5, we enter the category "Providing health care" and Subcategories of signification within the mission of the hospitals and some registration units. From the analysis of Table 5, we highlight the categories that emerged from content analysis: Provision of care with the subcategories Health needs $(5.5 \%)$, Treatment of the disease $(72.2 \%)$, Health promotion (19.4\%), Prevention (8.3\%), Rehabilitation $(5.4 \%)$, Health education $(2.7 \%)$, and Palliation $(2.7 \%)$.

By analyzing the content of the web pages on the mission of the hospitals from Tables 2 to 5, the categories with the highest expression are: Quality and excellence, Rigor in management, Provision of care, Ethics, Education/training/research, Innovation, Value creation and Spirituality.

Table 6 reflects the results that express the values and/or principles that the hospitals in the North Zone are continuing. We also present some categories and registration units that emerged from the analysis of the data content.

From the results obtained in the values that hospitals express on their websites the following categories have emerged: Quality (25\%), Access (8.3\%), Integrity (13.8\%), Management and organization (94.4\%), Service (11.1\%), Courtesy (33.3\%), Teamwork (36.1\%), Sense of belonging (11.1\%), Respect for the oneness and centrality of the person (100\%), Health promotion (33.3\%), Competence (30.6\%), Excellence (30.6\%), Responsibility (50\%), Innovation (30.6\%), Spirituality (5.6\%), Ethics (91.6\%), Human dignity (36.1\%), Humanization $36.1 \%$ ), Realization and satisfaction $(8.3 \%)$, Lifelong learning (38.8\%), Social and environmental responsibility (30.5\%), Ambition (11.1\%), Solidarity (2.7\%), Commitment (5.5\%), and Engagement (11.1\%).
In descending order, the figures that stand out are the following: Respect for the oneness and centrality of the person, Management and organization, Ethics and Responsibility.

In Table 7, we refer to the categories that emerged in the vision of the hospitals as well as some registration units. Hospitals in this study express their vision on their website within these categories: Valorization of users $(8.3 \%)$, Valorization of employees $(8.3 \%)$, Community valorization $(2.7 \%)$, Coordination between services $(5.5 \%)$, Excellence $(13.8 \%)$, Access and equity (8.3\%), and also the categories Education/ research (8.3\%), Sustainability (30.5\%), To be a reference in the industry $(77.7 \%)$, Change $(11.1 \%)$, Innovation (16.6\%), Expansion (2.7\%), Modernization (8.3\%) and Training and development $(11.1 \%)$. We can observe greater emphasis related to the intention of being a reference in the sector, openness to innovation and the search for excellence.

In Table 8, we present the category "Ethics" and subcategories of signification that emerged from the vision of hospitals as well as some registration units with higher expression of ethical references. Regarding Ethics, we find the subcategories Values (25\%), Humanization (19.4\%) and Social responsibility $(5.5 \%)$.

In Table 9, we expose the category "Recognition for the quality" and subcategories of signification that emerged in the vision of hospitals as well as some registration units with greater significance. A large percentage of the hospitals want to achieve recognition for the quality. In descending order the following subcategories are highlighted: Clinical Quality $(80.5 \%)$, of Management (25\%) and Organizational (11.1\%). 
Table 6. Categories and registration units in the values and/or principles of the hospitals

\begin{tabular}{|c|c|c|}
\hline Categories & A few registration units & $\%$ \\
\hline Quality & $\begin{array}{l}- \text {...higher levels of results and service } \\
\text { • High quality and clinical safety } \\
\text { •....achieve the best results, surpassing the expectations of our customers, employees and partners }\end{array}$ & 25.0 \\
\hline Integrity & - Promote a workforce to act in an open and integrated way. & 13.8 \\
\hline $\begin{array}{l}\text { Management and } \\
\text { Organization }\end{array}$ & $\begin{array}{l}\text { - Take on the agility procedures, strategic planning and the efficiency and sustainability as the main organizational guidelines (...) a less hierarchical structure } \\
\text { and continued ability to adapt to change } \\
\text { - Development of partnerships with other institutions } \\
\text { - Optimize the use of units } \\
\text { - Effectiveness } \\
\text { - Efficiency } \\
\text { - Maximize health gains } \\
\text { - Performance using community resources efficiently } \\
\text { - The management quality based on technical, human, economic and financial criteria. } \\
\text { - Market orientation, promoting customer satisfaction and loyalty } \\
\text { - Always keep in mind the values and expectations of our shareholders and, above all, our customers } \\
\text { - Value creation, continuously improving performance and recognizing the merit in the stakeholders' assessment }\end{array}$ & 94.4 \\
\hline Service & $\begin{array}{l}\text { - Service attitude } \\
\text { - Customer Dedication }\end{array}$ & 11.1 \\
\hline Courtesy & $\begin{array}{l}\text { - Spirit of collaboration and professional courtesy in the relationship with users } \\
\text { - Professional courtesy in relationships with co-workers }\end{array}$ & 33.3 \\
\hline Team work & $\begin{array}{l}\text { - Culture of working in a team and good relationship ... } \\
\text { • Internal culture of multidisciplinary and teamwork }\end{array}$ & 36.1 \\
\hline Sense of belonging & $\begin{array}{l}\text { - Pride and sense of belonging } \\
\text { - Building a genuine sense of belonging }\end{array}$ & 11.1 \\
\hline $\begin{array}{l}\text { Respect for the oneness } \\
\text { and centrality of the } \\
\text { person }\end{array}$ & $\begin{array}{l}\text { - Respect, by recognizing the uniqueness of each person seeking their services } \\
\text { - The primacy of the patient } \\
\text { - Identify and meet the needs of care with dignity, kindness and humanism } \\
\text { - Respect for the individual seeking to respond to the needs of patients and employees, with respect for privacy and encouraging their participation in decision } \\
\text { making }\end{array}$ & 100 \\
\hline Health Promotion & - Attitude/orientation focused on health promotion in the community & 33.3 \\
\hline Competence & $\begin{array}{l}\text { - ... promoting and sharing responsibilities as a team ... ensuring the goals of the institution and Professionalism } \\
\text { - Promote competence and motivation }\end{array}$ & 30.6 \\
\hline Excellence & $\begin{array}{l}\text { - Culture of medical/technical excellence and care } \\
\text { - Provide a service of excellence }\end{array}$ & 30.6 \\
\hline Innovation & - Stimulate creativity and spirit of innovation, encouraging individual initiative and developing new activities in order to ensure the best care for their patients & 30.6 \\
\hline Spirituality & $\begin{array}{l}\text { - Spirituality } \\
\text { - Solidarity and Christian Values }\end{array}$ & 5.6 \\
\hline Ethics & $\begin{array}{l}\text {-... high standards of ethical behavior } \\
\text { - Comply with the principles and procedures defined for the Institution, working with honesty, professionalism and transparency } \\
\text { - Decisions will be honest in the best interests of the community they serve } \\
\text { - Advocating the highest ethical principles of conduct in all actions and decisions ... } \\
\text { - Respect the confidentiality and privacy of the person's integrity and altruism } \\
\text {-... defense of ethical and moral values }\end{array}$ & 91.6 \\
\hline Human Dignity & $\begin{array}{l}\text { - Paramount value of human dignity } \\
\text { - Full respect for the Dignity and Rights of Human Beings } \\
\text { - Respect for human dignity by recognizing the uniqueness of each person seeking their services } \\
\text { - Recognition of the dignity and the unique character of each person }\end{array}$ & 36.1 \\
\hline Humanization & $\begin{array}{l}\cdot \ldots \text { the human part of the professionals will have to override the technical part } \\
\cdot \ldots \text { always offering a humanized service } \\
\text { - favoring a personal relationship, listening and responding to the concerns and needs }\end{array}$ & 36.1 \\
\hline $\begin{array}{l}\text { Fulfillment and } \\
\text { Satisfaction }\end{array}$ & $\begin{array}{l}\text { - Being a hospital that promotes the achievement, the personal and professional satisfaction of all employees } \\
\text { - Personal development } \\
\text { - Employee motivation }\end{array}$ & 8.3 \\
\hline Lifelong learning & $\begin{array}{l}\text { - Learn from the people who make use of clinical services, with the human resources of the institution and with the best practices of the NHS and beyond } \\
\text { - Culture of knowledge as a good in itself } \\
\text { - Will use the best available scientific evidence in providing effective services, both in terms of clinical outcomes, as in the use of financial resources, among } \\
\text { others } \\
\text { - Betting on the personal and professional development of our employees ... }\end{array}$ & 38.8 \\
\hline $\begin{array}{l}\text { Social and environmental } \\
\text { responsibility }\end{array}$ & $\begin{array}{l}- \text {... Sustainable development of the society, favoring the full exercise of citizenship and respect for the environment } \\
\text { - Taking the permanent responsibility of maintaining the environmental balance with its internal and external surroundings }\end{array}$ & 30.5 \\
\hline Ambition & $\begin{array}{l}\text { - Expansion } \\
\text { •... develop the best solutions, products and services }\end{array}$ & 11.1 \\
\hline Solidarity & • Solidarity & 2.7 \\
\hline Commitment & $\begin{array}{l}\text { - Customer commitment } \\
\text { • Ensuring that the customer always comes first ... }\end{array}$ & 5.5 \\
\hline Engagement & - Applying passion, innovation and creativity in what we do & 11.1 \\
\hline
\end{tabular}


Table 7. Categories and registration units of the vision of the hospitals

\begin{tabular}{|c|c|c|}
\hline Category & A few registration units & $\%$ \\
\hline Valorization of users & - Be a reference institution in terms of user satisfaction ... & 8.3 \\
\hline Valorization of employees & - Professional and personal fulfillment of our staff ... & 8.3 \\
\hline Community valorization & - Satisfaction of the surrounding community ... & 2.7 \\
\hline Articulation & - Excellent coordination of all services & 5.5 \\
\hline Excellence & $\begin{array}{l}\text { - Being a hospital of reference... } \\
\text { - Deserve the natural preference of customers }\end{array}$ & 13.8 \\
\hline Access and equity & $\begin{array}{l}\text { - Health care provision to the population of their area of influence, without prejudice to the right of free choice from } \\
\text { patients originating from other geographical areas } \\
\text { - Promotion of equity of access ... }\end{array}$ & 8.3 \\
\hline Teaching/research & $\begin{array}{l}\text {-... pre and post-graduate education } \\
\text { • Encouraging research and scientific development, in conjunction with health centers and other integrated hospitals in } \\
\text { the National Health Service } \\
\text { • Participation in research and postgraduate education }\end{array}$ & 8.3 \\
\hline Sustentability & $\begin{array}{l}\text {-... economic and financial balance of the Hospital } \\
\text { •... being a hospital of reference ... in the efficient use of financial resources that the community gives us, through the } \\
\text { budget of the National Health Service } \\
\text { • Solidity and rigor as a support to the activity and results } \\
\text { - Perspective of sustainable growth... } \\
\text { - Consolidate and expand the maturity of the group ... }\end{array}$ & 30.5 \\
\hline $\begin{array}{l}\text { To be a reference in the } \\
\text { sector }\end{array}$ & $\begin{array}{l}\text { - Being a referral hospital for the entire National Health Service } \\
\text { - Being a reference model for other health care providers } \\
\text { - Being the best hospital (...), positioned in the first } 10 \text { places in the national ranking of corporate hospitals } \\
\text { - Being a reference model as an institution, bringing people together... } \\
\text { - Being a leader in providing health care ... } \\
\text { - The Hospital is recognized by the community as a quality establishment in health } \\
\text { - Being a national and European reference in the sector of Health and Welfare } \\
\text { - Creating value for its public } \\
\text { - Increasing the supply and value creation }\end{array}$ & 77.7 \\
\hline Change & $\begin{array}{l}\text { - Commitment to change } \\
\text { - Sense of change and differentiation }\end{array}$ & 11.1 \\
\hline Innovation & $\begin{array}{l}\text { - Practice of an innovative medicine } \\
\text { - Innovation as a premise of selecting methods, frameworks and technologies } \\
\text { - Innovation at a strategic level and the organizational level }\end{array}$ & 16.6 \\
\hline Expansion & - Providing growth options in selected international markets & 2.7 \\
\hline Modernization & $\begin{array}{l}\text { - Consolidate the path of modernity and the necessary innovation } \\
\text { - Investment in the modernization of our hospital ... }\end{array}$ & 8.3 \\
\hline Training and development & $\begin{array}{l}\text { - Develop research activities, training and education for the benefit of its employees, in cooperation with the various } \\
\text { educational institutions, hospitals and other health institutions }\end{array}$ & 11.1 \\
\hline
\end{tabular}

Table 8. Category "Ethics" and Subcategories of signification of the vision of the hospitals

\begin{tabular}{lll}
\hline Subcategories & A few registration units & \% \\
\hline Values & - Dignity as a transversal vector of a holistic and friendly performance & 25.0 \\
& - Transparency regarding our actions, which go beyond our sphere of influence & \\
Humanization & - Creating an integrated network of humanized health care and social support based on the principles of hospitality & \\
& - Humanism as a transversal vector of a holistic and friendly performance & \\
Social responsibility & - Consolidation of affections, human development and customer appreciation & \\
\hline
\end{tabular}

\section{DISCUSSION}

In order to achieve its objectives and tasks, each hospital, in its conceptual matrix, incorporates evidence of the vision, mission, values and/or principles, demonstrating harmony with Rodríguez ${ }^{[3]}$ when he points out that the hospital should disclose the mission, philosophy, values, principles and rules that constitute a code of ethics, for this is a subject with

Published by Sciedu Press moral, legal and social responsibility.

In this study we have found that hospitals, whether they are integrated into the National Health Service (legal status of Public-Private Partnership or Public Enterprise), whether they are from the Private or Social Sectors, feature explicitly their values, mission and vision, regardless of the implemented management model. 
Table 9. Category "Recognition for the quality" and subcategories of signification in the vision of the hospitals

\begin{tabular}{|c|c|c|}
\hline Subcategories & A few registration units & $\%$ \\
\hline Clinical & $\begin{array}{l}\text { - The Hospital is recognized by the community as a quality establishment in health } \\
\text { - Raising quality standards in providing personalized healthcare } \\
\text { - Quality in the biopsychosocial and spiritual perspective of the people who come to us } \\
\text { - Quality of care provided to users and in clinical management } \\
\text { - Maximum cure rates ... } \\
\text { - Ensuring the best medical diagnosis and treatment that the talent, innovation and dedication can provide } \\
\text { - Excellence of the results obtained in various specialties at its disposal } \\
\text { - Minimum treatment times ... } \\
\text { - Ensuring continuity of care that responds to the evolution of health needs throughout people's lives }\end{array}$ & 80.5 \\
\hline Organizational & $\begin{array}{l}\text { - Optimized organization to provide integrated health care } \\
\text { - Be recognized for the excellence of the organization }\end{array}$ & 11.1 \\
\hline Management & $\begin{array}{l}\text { - Ongoing challenge of good management practices as a reality } \\
\text { - Management with dynamic planning that enhances the optimization of human and material resources } \\
\text { - Systematic assessment of procedures } \\
\text {-... Being a reference institution within the North, in terms of efficiency and effectiveness in the implementation of } \\
\text { financial and material resources }\end{array}$ & 25.0 \\
\hline
\end{tabular}

As for the hospital's mission, while other categories can integrate it, six of them expressly assume spirituality and two of them state it in their reference values. All of the hospitals claim to possess ethical values, expressing the need to promote human dignity, the quality in the various areas and holistic care to be provided. The concern of the private sector to add value for its employees, recipients and shareholders stands out. We noticed that only five of the hospitals under study did not express their vision of the future.

Addressing the ethical dimension of management, Costa states that "... no one can assume high levels of engage ment and commitment towards the organization to which it belongs if a clear consistency between declared principles developed and practices is not perceived." ${ }^{[6]}$

This study shows that most hospitals define their mission, vision and values, while others add their principles and/or objectives. Thus, from their values some hospitals deduce the principles, which operationalize in rules governing the action. However, because of the difficulty in establishing watertight compartments between values and principles, we agree with Anunciação and Zoboli ${ }^{[9]}$ who, in their research, used principles and values as synonyms. We have therefore almost homogeneous contents and sometimes even overlapping, between the mission, values and vision directed to the quality of health care, clinical area and the technical and organizational management, valuing the person in its dignity, with a strong focus on the ethical paradigm of personalism, responsibility and care.

We observe reciprocity between the publication of the mission, values and vision by the North Regional Health Authority and the one set by each hospital, possibly because that organization has become an essential reference.
As expected, all of the hospitals inserted within its mission the quality and excellence, provision of special care in the identification of health needs, treatment, promotion, prevention, rehabilitation and ethics as a management strategy, with a strong increase of humanization and the centrality in the person. The service quality, the perceived value, the image, the involvement and equity significantly influence the user satisfaction. ${ }^{[14]}$ Therefore "...achieving the best results, surpassing the expectations of (...) customers, employees and partners" (H18) is a requirement for the current functioning of hospitals which is perceived in the declared contents in the web pages of all hospitals. In this perspective, the results obtained refer to the consideration that the defined mission, vision and values are formed as the patterns that lead their practice to excellence.

The concern that the ethical, social and environmental responsibility are today emerging issues for combining social welfare with the hospital's performance is something that stands out. We note, therefore, that managers of hospitals, while true to their social mission, are attentive to the consideration to meet the financial and environmental sustainability, opting for socially responsible management, referring the conviction of "assuming permanent responsibility to maintain the environmental balance with its internal and external surroundings" (H9).

The results show the need to ensure sustainability, in that it is intended, for example, “... to be a hospital of reference (...) in the efficient use of financial resources that the community (...) attributes, through the budget of the National Health Service" (H16). In fact, the change of social paradigm turns into a growing need to rethink the issue of the support of organizations. In this context, hospitals are organized in order to 
"take agility of procedures, strategic planning, efficiency and sustainability as the main organizational guidelines ..." (H9). In this sense, they seek strategies to reduce waste, manage efficiently and effectively in the application of human and financial resources, and minimize the environmental impact of their work processes. Thus, the environmental ethics and the investment in conservation and environmental education is also essential, considering nature as a value.

When we think of sustainability and social responsibility, we mean that companies not only have the responsibility to recycle or support an institution, as should also link up to the constant concern for continuous improvement. That is, acting with underlying ethical values and quality of life, whether they have internal or external customers, and the preservation of the environment, which involves the ethical management of natural resources, emphasizing the need for a "... sustained society development, favoring the full exercise of citizenship and respect for the environment" (H14). All hospitals should have a leading role in contributing to environmental excellence by encouraging sustainable development and the well-being of their communities. However, we found that only a small percentage of hospitals (30.5\%) position themselves within social and environmental responsibility.

In our perspective, the contents inserted in the mission of every hospital promote good practice by an ethical culture of quality of service, humanization and respect for the dignity of each person. We believe that the existence of consistency between the values expressed in the mission and its translation into the reality of the institutions are success factors that should be considered for successful organizations by the leading role of professionals, particularly in management, development and support of institutional strategic initiatives in the area of clinical governance.

The vision of the future turns out to be a commitment to internal and external customers and the whole society. The planning, the strategies used and the resource allocation should reflect the vision of the future. Only a comprehensive view allows to identify specific objectives and evaluate the performance of the institution. It is in this context that the vision of the hospital lies in the opportunity to be "(...) an institution of reference within the Northern area, in terms of efficiency and effectiveness in the implementation of financial and material resources" (H22). The concept of good corporate governance is not univocal, it gathers various topics ranging from the creation of value, the conflicts of interest, compliance with laws, regulations and codes of conduct, the decisionmaking processes, internal control, information disclosure and accountability/responsibility. ${ }^{[15]}$
The results reveal that hospitals, at least in what they convey through their web page, value "respect for human dignity, by recognizing the uniqueness of each person seeking their services" (H3), because they consider that "the human being has an ontological dignity which is inalienable and indestructible". ${ }^{[16]}$ In our perspective, the contents inserted in the mission of every hospital promote good practice by an ethical culture of quality of service, humanization and respect for the dignity of each person.

The relationship between those who provide care and those who receive care has to necessarily be guided by principles and values, of which human dignity is the pillar that supports all other principles. Human dignity must be present in an absolutely unequivocal way in any intervention. ${ }^{[17]}$

Hospital management is an ethically responsible and competent commitment through participative management, centered on people and integrated with objectives. These objectives are aimed at achieving health outcomes for the population with the treatment or prevention, wellness, professional, social and human valorization of its employees and organizational efficiency. The documental analysis revealed an "absolute respect for fair conduct and for promoting equality of opportunities and treatment to all people looking for (...) services" (H29). This demonstrates, therefore, that "there is good access when patients can get the right service at the right time and the right place". ${ }^{[18]}$

In summary, we verified that according to the definition of the mission, values and vision of the hospitals, the multiple categories concentrate on assistance, organization and management, quality, ethics and social responsibility. The expression of spirituality is reduced to two hospitals. As for the hospital's mission, six of them expressly assume spirituality.

In the research of Anunciação and Zoboli ${ }^{[9]}$ the values found in literature and on the web sites of 30 hospitals in Brazil have been grouped in the following categories: assistance, administration and social commitment.

Our time seems to coincide with a crisis of values and this crisis is anthropological, ecological and economic. However, with this study, we realized that hospital managers recognize that ethics and human values are the foundation for the functioning of these institutions. Moreover, they have in mind that the mission, values and vision constitute accreditation criteria, which is why, in the social sector, they are declared in the Quality Policy, while hospitals with a Public Enterprise management model recognize that they have a global reach, framing them in the institutional code of ethics. 


\section{Conclusion}

In the mission, values and vision displayed on the web pages of health institutions, the promotion of ethical and moral values is notorious, especially the respect for human life, the humanization of health care and the quality of care and social responsibility, with little expression of spirituality.

The results of this study reflect a very broad consensus of humanistic ethical values of health professionals in general and particularly in managers. They refer back to the consideration that the mission, vision and values are constituted as the standards that must conduct its practice into excellence, since the value system focuses on the comprehensive care of people whether they are users of services or collaborators of the institution.

Health professionals find in their code of ethics the ethical dimension and expression of duties, most of which related to safeguarding the rights of people in their care. In the mission, vision and values they find the framework of guiding principles for achieving the standards of performance that also express the organizational culture. In this context, acting ethically is a decision that belongs to each person and the contribution of everyone is important for the hospital to be ethical.

\section{CONFlicts OF InTEREST Disclosure}

Authors declare that they have no competing interests.

\section{REFERENCES}

[1] Massarolo MCKB, Fernandes MFP. In: Kurcgant, Paulina (Coord.) Gerenciamento em Enfermagem [Nursing Management], $2^{\text {nd }}$ Ed., Rio Janeiro: Guanabara Koogan; 2010.

[2] Flores FJR. Gestion Hospitalaria y Justicia Social [Hospital Management and Social Justice]. In: Brito, J.H.S. (Coord.) Ética, Justiça e Cuidados de Saúde [Ethics, Justice and Healthcare]. Braga: Universidade Católica Portuguesa, Faculdade de Filosofia; 2009.

[3] Rodríguez GH. El hospital como organismo ético [The hospital as an ethical organism]. Cuadernos de Bioética [Bioethics Journals]. 2008; 19(67): 423-432.

[4] Almeida F. Editorial, Encontro 25 anos do CEB Cadernos de Bioética [Bioethics Journals]. Centro de Estudos de Bioética. 2014; 19: 7-10.

[5] Rego A, Araújo B. Enfermagem: gerir com vinculação a valores [Nursing: managing with a link to values]. Revista Servir. 2013; 58(1-2).

[6] Costa R. PERSONA, Manual prático de Gestão das Pessoas [Practical Handbook of People Management]. Lisboa: Bertrand Editora; 2003.

[7] Mezomo JC. Gestão da qualidade na saúde: Princípios básicos [Quality management in health: The basics]. Brasil: Editora Manole Lda; 2001.

[8] Zoboli ELCP, Fracolli LA. A incorporação de valores na gestão das unidades de saúde: chave para o acolhimento [The incorporation of values in health facility management: the key to hosting]. O Mundo da Saúde [The World of Health]. São Paulo. 2006; 30(2): 312-317.

[9] Anunciação AL, Zoboli E. Hospital: Valores éticos que expressam sua missão [Hospital: Ethical values that express its mission], Rev. Assoc. Med. Bras. São Paulo. 2008; 54(6): 522-528. http://dx.doi.org/10.1590/S0104-42302008000600017

[10] Tiffany P, Peterson S. Planejamento estratégico: o melhor roteiro para um planejamento estratégico eficaz [Strategic planning: the best itinerary for effective strategic planning]. Rio de Janeiro: Campus; 1998.
[11] Administração Regional de Saúde do Norte. Plano de Atividades. 2013 [North Regional Health Authority. 2013 Business Plan] Available from: http://portal.arsnorte.min-saude.pt/po rtal/page/portal/ARSNorte/A\%20ARS\%20Norte/Instrume ntos $\% 20$ de $\% 20$ Gest $\%$ C3\%A3o/Ficheiros/Plano_Atividades _ARSN_2013.pdf

[12] Administração Central do Sistema de Saúde [Central Administration of the Health System]. I. P. (ACSS). 2015. Available from: http://benchmarking.acss.min-saude.pt/monitorm ensal/groupcapacidade/capacidade2015.aspx

[13] Bardin L. Análise de Conteúdo [Content Analysis]. Lisboa: Edições $70 ; 2011$.

[14] Pinheiro PAP. Avaliação da satisfação dos utentes num Serviço de saúde hospitalar (Dissertação de mestrado) [Users' satisfaction assessment in hospital health service (Master's thesis)]. Universidade de Aveiro, Departamento de Economia, Gestão e Engenharia Industrial; 2013. Available from: https ://ria.ua.pt/bitstream/10 773/11441/1/Disserta\%C3\%A7\%C3\%A3o.pdf

[15] Ribeiro JAM (Coord.). Final Report carried out by the Technical Group for the Hospital Reform established by Order No. 10.601/2011 of the Minister of Health, published in the official Republic Diary No. 162, $2^{\text {nd }}$ Series, of 24 August 2011.

[16] Mezzomo AA. Fundamentos da humanização hospitalar - uma visão holística [Fundaments of hospital humanization - a holistic view] Bioethikos. 2012; 6 (2): 217-221.

[17] Mendes G. A dimensão ética do agir e as questões da qualidade colocadas face aos cuidados de enfermagem [The ethical dimension of action and the questions of quality facing nursing care]. Texto \& Contexto - Enfermagem [Text \& Context - Nursing]. 2009; 18(1): 165 169. http://dx.doi.org/10.1590/S0104-070720090001000 20

[18] Chapman JL, Zechel A, Carter YH, et al. Systematic review of recent innovation in service provision to improve accss to primary care. British Journal of General Practice. 2004; 54 (502): 374-381. PMid: 15113523. 